\title{
Interattività e interoperabilità nel disegno a mano libera: alcuni approcci digitali a supporto della didattica
}

\author{
Maurizio Marco Bocconcino \\ Francesca Maria Ugliotti
}

Abstract

Nell'ambito della rivoluzione digitale il concetto di 'connessione' assume una valenza cruciale, abilitando una visione trasversale di saperi, tecniche e strumenti. L'interscambio di dati in ambienti informatici è regolato dalla capacità di interagire e funzionare, misurata nel grado di 'interoperabilità', che mira a garantire la migliore cooperazione tra sistemi o prodotti. L'articolo si propone di indagare la relazione tra il disegno analogico e la sua riformulazione digitale - assistita, ridefinita, ristrutturata, conformata, parametrizzata, perfino virtualizzata - vagliando nuove possibilità di concepire e costruire la rappresentazione, sia come schematizzazione grafica di un pensiero, in forma artistica o in forma tecnica, sia come strumento per comprendere o prefigurare. Specifici supporti hardware e software mirano a instaurare un continuum tra il tratto condotto a mano libera e la sua formulazione analitica all'interno della gestione informatica. In questo senso, si introducono provocatoriamente termini come interattività e interoperabilità, non immediatamente associabili al disegno condotto a mano libera: la didattica del disegno si confronta su questi approcci con sempre maggiori aspettative, valutando le opportunità e le modalità di inserimento di mirate esperienze formative, traguardando già nei primi anni accademici metodi e tecniche di rappresentazione utili per un arricchimento del profilo del futuro architetto o ingegnere.

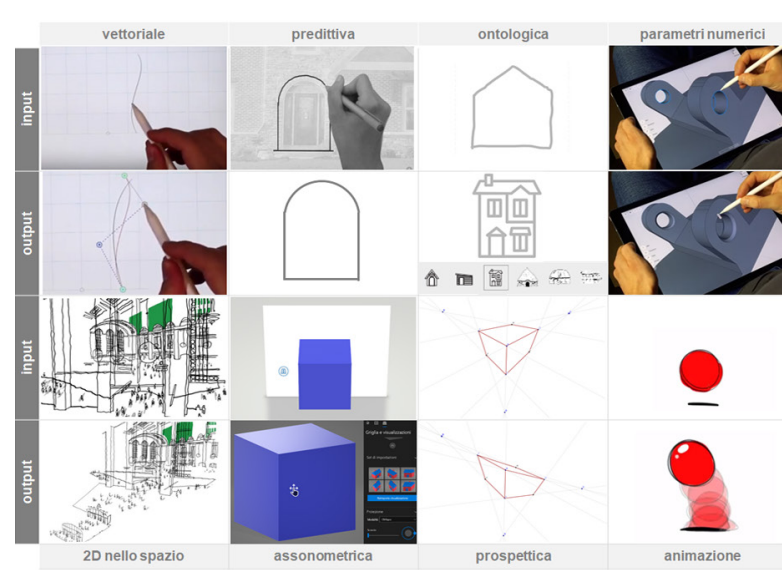

2D nello spazio assonometrica

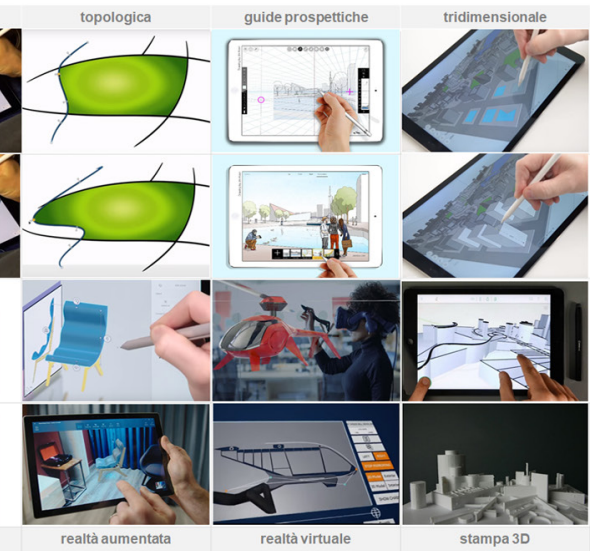




\section{Introduzione}

In un mondo sempre più competitivo in termini di efficacia ed efficienza richiesta ai processi di conoscenza e di progetto, le capacità digitali nella gestione dei sistemi di rappresentazione diventano elemento essenziale e discriminante. II disegno, in quanto linguaggio grafico, informativo e plurimediale, trova espressioni diverse in relazione agli strumenti utilizzati. L'obiettivo da più parti condiviso è quello di tentare di concepire un modello informativo, gemello 'intelligente' dell'oggetto reale o immaginato, da predisporre ed elaborare per governare la sua struttura formale e garantire la trasferibilità delle informazioni a esso associate e da esso prodotte. II contributo fornisce una sintesi ragionata, non esaustiva, degli strumenti grafici hardware e software che supportano il disegno. La sua originalità crediamo sia individuabile nella circostanza di promuovere un terreno di confronto e di discussione allargata (quali nuovi strumenti, servono o non servono, aggiungono o sottraggono, cosa sommano e cosa tolgono), in termini critici e con finalità di descrizione in progress, via via più definita, del panorama degli applicativi di supporto. Le figure che accompagnano il testo e restituiscono questo primo lavoro analitico, insieme ai riferimenti bibliografici, vogliono in questo campo
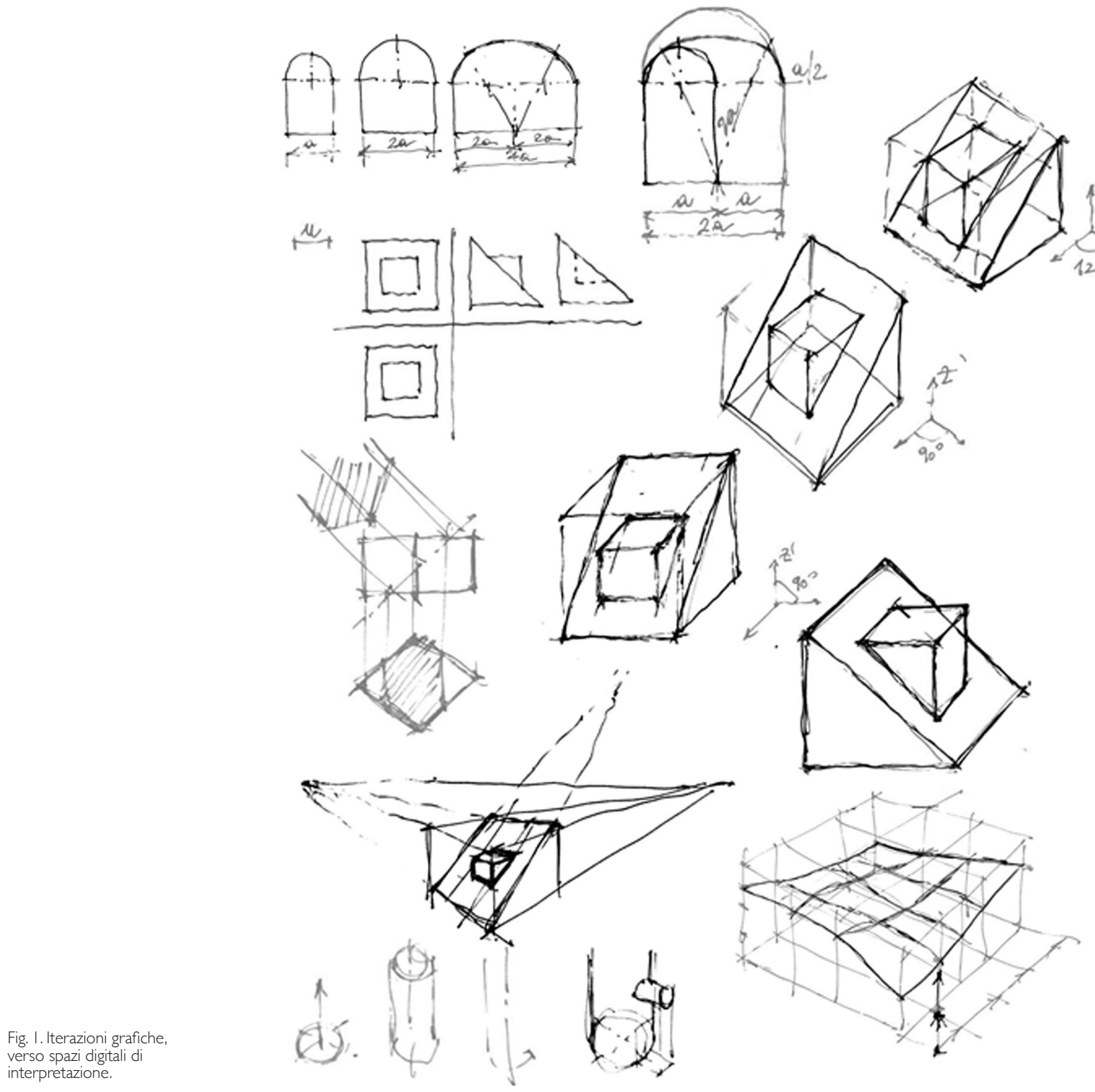
fornire quadri sinottici di confronto, utili per approfondimenti e integrazioni successive maggiormente esaustive. Questa prima fase di ricerca inizia a costruire uno stato dell'arte utile a valutare l'evoluzione degli strumenti e le possibilità offerte dagli stessi in un quadro necessariamente in costante aggiornamento e quindi mutevole. In questo senso, nella rassegna critica si è comunque voluto ricomprendere strumenti grafici non specificamente dedicati al disegno a mano libera, ma strumenti analitici di analisi grafica interattiva che assistono la costruzione geometrica nello spazio di enti geometrici fondamentali e la loro relativa nomenclatura descrittiva. (M.M.B.).

\section{Alcune considerazioni di carattere metodologico}

"L'uso del disegno digitale diventa un mezzo utile per rendere più rapido e didatticamente efficace l'esercizio per la rappresentazione dei contenuti spaziali e della loro corretta restituzione nei modelli proiettivi consueti, se condotto con logica rigorosa, senza tralasciare il disegno "a mano libera", bensì sfruttando le specifiche caratteristiche di entrambi" [Altadonna, Arena, Manganaro 2018, p. 18]. Così Mario Manganaro si esprimeva sulla didattica del disegno. Di fronte al disegno a mano libera, che studia ed evidenzia forme, rapporti, proporzioni compositive che non è spesso possibile raccogliere 'a colpo d'occhio', a qualcuno può essere capitato di chiedere qualcosa di più di quanto esso già non restituisca. Entrare nella scena, modificare il punto di vista man mano che ci si addentra, applicare altre regole proiettive, anche più raffinate rispetto a quelle prospettiche, come quelle applicate a piani paralleli o ortogonali a quelli principali nella scena. In qualche modo, con sempre maggiore numerosità si stanno affacciando nel panorama delle applicazioni informatiche strumenti che assistono il disegno a mano libera con diversi gradi di risposta, alcuni spingendosi fino alla interpretazione spaziale di quanto disegnato sul piano della carta o dello schermo. La relazione biunivoca che si instaura tra figura nello spazio e immagine sul piano di proiezione è la nostra materia prima; essa viene elaborata all'interno di questi software.

Il metodo della prospettiva inversa o la restituzione a ritroso della configurazione geometrica tridimensionale a partire da proiezioni assonometriche sono gli ambiti applicativi più frequenti negli esempi qui avvicinati. Il problema spaziale della determinazione di un solido date le sue viste in proiezione ortogonale appare invece, come ci aspettiamo, non risolto; elevato è il grado di astrazione concettuale, tanto da poter essere determinato, per ora, solo da quella potente macchina della visione che sta nella scatola cranica dei soggetti maggiormente allenati, non è possibile per un calcolatore, o meglio, ancora nelle applicazioni analizzate non è stato portato a cimentarsi nell'affrontare in maniera sintetica l'esercizio, se non mettendo in campo la potenza del calcolo che può prefigurare miliardi di soluzioni progressivamente più aderenti a quella cercata, probabilmente senza far convergere l'iterazione verso il modello più confacente [Bocconcino et al. 20 I0]. La geometria piana e solida, quella descrittiva, e quella proiettiva trovano nuovi ambienti di espressione; la genesi spaziale degli elementi nei diversi ambienti di elaborazione si costruisce in maniera interattiva tra l'osservatore che disegna e lo spazio di elaborazione allinterno del quale si muove (fig. I). Scrive Le Corbusier che attraverso la matita "le cose restano dentro [di noi] per la vita", aggiungendo poi "l'apparecchio fotografico è utensile della pigrizia perché affida a un meccanismo la missione di vedere per noi. Disegnare personalmente, seguire dei profili, occupare delle superfici, riconoscere dei volumi ecc., è innanzitutto guardare, è forse essere atti a osservare, forse atti a scoprire. In quel momento il fenomeno dell'invenzione può sopraggiungere. Si inventa e anche si crea; tutto l'essere è trascinato nell'azione, questa azione è il punto capitale. Gli 'altri' sono rimasti passivi, voi avete visto!' [Le Corbusier 1987, p. 9I]. Nelle successive considerazioni non si vogliono fornire nuovi utensili alla pigrizia; nel cercare di scardinare i nodi della visione concettuale dello spazio nella mente dei giovani allievi, ogni strumento appare lecito. II sottile meccanismo della visione e della concezione spaziale si perfeziona seguendo strade personali per ognuno: quante più è possibile fornirne allo studente, tanto più egli potrà magari riconoscere la propria. (MMB, FMU). 


\section{Prima rassegna critica degli strumenti di supporto digitale al disegno a mano libera}

Nel mondo dell'ingegneria e dell'architettura, l'adozione di strumenti informatici è finalizzata alla risoluzione più efficiente di problemi complessi. Le applicazioni di tipo grafico giocano un ruolo importante in questo contesto in quanto consentono di riprodurre e visualizzare un oggetto nello spazio a partire da una rappresentazione bidimensionale. Eisenman sostiene che il computer dà la possibilità di realizzare cose che non si potrebbero fare direttamente, dalla concezione mentale alla esecuzione a mano, e promuove un processo di affinamento continuo dei modelli concettualizzati [Galofaro 1999]. L'evoluzione digitale ha introdotto cambiamenti epocali nell'ambito della produzione delle immagini e del disegno tecnico, il primo negli anni Settanta quando si è assistito al passaggio dal tecnigrafo ai sistemi di progettazione assistita Computer Aided Design (CAD); il secondo negli anni Duemila

iOS

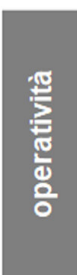

android

con l'avvento della metodologia basata sulla modellazione digitale parametrica Building Information Modelling (BIM). Grazie alle Information and Communication Tecnologies (ICT), la creatività dei progettisti è supportata da sistemi sempre più evoluti di generazione $\mathrm{e}$ controllo. Focalizzando l'attenzione sulla trasformazione digitale dell'input analogico, i principali strumenti hardware si sono sviluppati a partire dall'invenzione dei digitalizzatori che hanno portato alla nascita degli schermi tattili, brevettati nel 1969 e inizialmente diffusi negli sportelli informativi e automatici per il pubblico. La tecnologia del digitalizzatore consente di ricevere informazioni analogiche - oggetti, immagini o segnali, e archiviarle in tempo reale

\begin{tabular}{|c|c|c|c|}
\hline appunti grafici & $\begin{array}{l}\text { geometria } \\
\text { descrittiva }\end{array}$ & $\begin{array}{c}\text { schizzo architettonico } \\
\text { urbano/territoriale }\end{array}$ & disegnotecnico \\
\hline $\begin{array}{l}\text { Sopra fogli o taccuini, } \\
\text { per annotare e formulare } \\
\text { relazioni geometriche } \\
\text { tratte da fonti transitorie } \\
\text { o immagini con il fine di } \\
\text { ricordare, leggere, } \\
\text { schematizzare, } \\
\text { semplificare. }\end{array}$ & $\begin{array}{l}\text { Rappresenta in modo } \\
\text { univoco, non ambiguo, } \\
\text { attraverso determinate } \\
\text { costruzioni geometriche, } \\
\text { mediante uno o più piani } \\
\text { di proiezione, figure nello } \\
\text { spazio tramite enti } \\
\text { geometrici fondamentali. }\end{array}$ & $\begin{array}{l}\text { Disegno schematico di edifici } \\
\text { o parti di edifici (eidotipo se } \\
\text { preparatorio a successivi } \\
\text { approfondimenti conoscitivi) } \\
\text { e del loro contesto urbano o } \\
\text { territoriale. } \\
\text { informazioni di contiene } \\
\text { quantitativo (in termini di } \\
\text { assialità, modularità ea } \\
\text { proporzioni) e qualitativo } \\
\text { (contesto, funzioni, materiali, } \\
\text { ecc.). }\end{array}$ & $\begin{array}{l}\text { Si occupa di fornire, } \\
\text { attraverso i metodi di } \\
\text { rappresentazione, dati di } \\
\text { misura e di forma utili per la } \\
\text { sezione di manufatti fisici di } \\
\text { vario genere. Ė una } \\
\text { rappresentazione di elementi } \\
\text { geometrici nello spazio, le } \\
\text { cui regole base sono dettate } \\
\text { dalla geometria descrittiva, } \\
\text { ai quali sono applicati codici } \\
\text { e standard grafici specifici } \\
\text { (normetecniche). }\end{array}$ \\
\hline
\end{tabular}

in un formato digitale gestibile da computer, sfruttando il principio dell'induzione elettromagnetica. A partire dagli anni Duemila tavolette grafiche e tablet sono stati prontamente adottati in ambiti specifici del disegno fortemente caratterizzati da funzioni di creatività, artistica e grafica, sfruttando la possibilità di collegamento di speciali periferiche per simulare il disegno a mano libera, quali pennini o aerografi. In particolare, ciò che viene tracciato mediante apposita penna sulla superficie della tavoletta grafica viene visualizzato sul monitor 


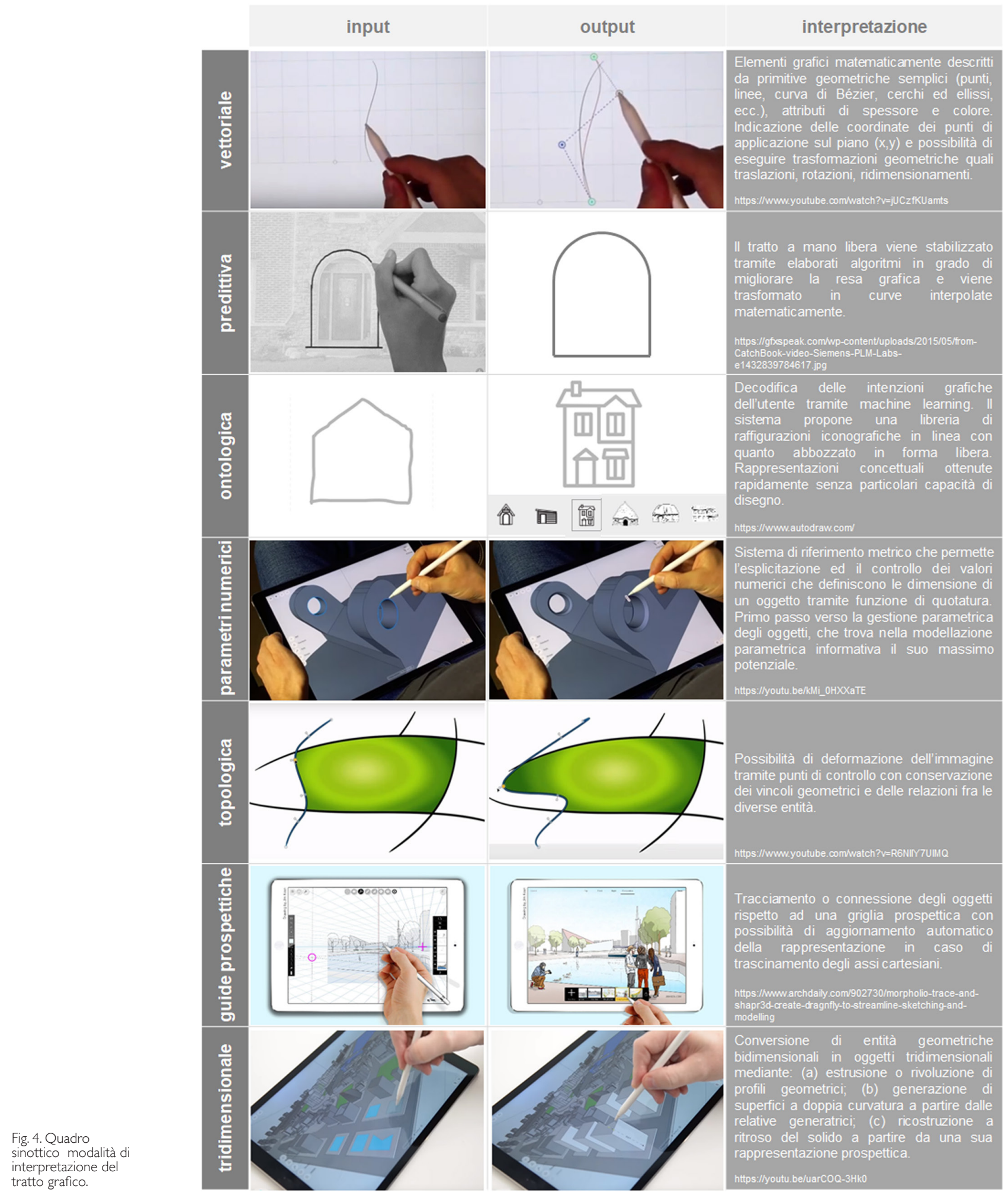




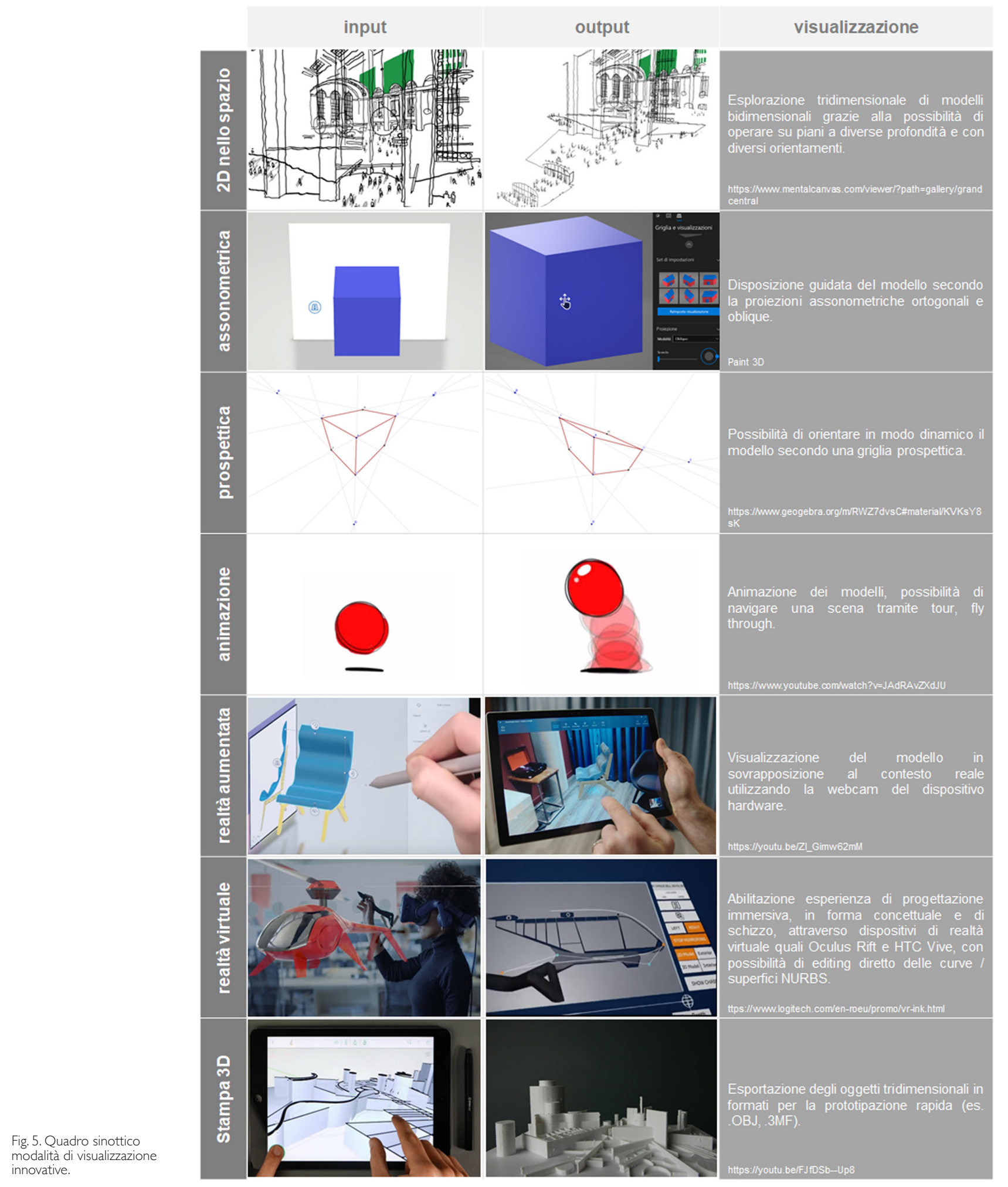


del computer; mentre è registrato direttamente su uno schermo resistivo o capacitivo nel caso del tablet. Gli aspetti che caratterizzano questi dispositivi sono molteplici: dalla usabilità alla facilità di utilizzo, dalla risoluzione alla sensibilità alla pressione dello schermo e al tipo di pennino. Si arricchiscono gli strumenti a disposizione per i professionisti ma contestualmente si ampliano gli utenti che possono ottenere risultati digitali senza abbandonare la scrittura e il disegno su carta attraverso sistemi di Smart Writing. Attraverso una speciale penna e un quaderno intelligente è infatti possibile trasferire istantaneamente appunti, bozze, schemi, schizzi, in cloud, trasformandoli in dati vettoriali (rocketbook.co.uk, 2020; moleskine-smart-writing-set 2020, livescribe SmartPen 2020). Altre possibilità tecnologiche consentono di progettare e realizzare figure solide nello spazio tramite penne 3D, che depositano filamenti plastici tramite l'ugello di un estrusore fino a materializzare quelle concepite virtualmente attraverso prototipazione rapida e stampa 3D. La buona interazione con i dispositivi hardware è conseguita tramite l'utilizzo di software dedicati che permettono la conversione della pressione delle dita o della periferica adottata in tratti grafici. Parte di questi strumenti si è evoluta inizialmente in ambienti di produzione industriale e automotive per assolvere a esigenze specifiche di gestione di curve parametriche nello spazio e prototipazione. L'interdipendenza tra occhio, mano e mente è estremamente utile all'apprendimento; in questo senso, i software di disegno si sono orientati negli ultimi anni a gestire la compresenza della forma tradizionale con quella digitale. Da una ricognizione preliminare della letteratura e del mercato, sono disponibili svariate applicazioni in grado di ottenere una soddisfacente qualità percettiva assolvendo al ruolo di strumento cognitivo svolto dal disegno. Le applicazioni riferite esclusivamente al disegno artistico, nonostante la loro ampissima diffusione, sono state escluse dalla rassegna, in quanto per ora non coincidenti con gli obiettivi dello studio, sebbene si sia considerata tale funzione. La tabella riportata in fig. 6 si configura come strumento grafico per agevolare il confronto tra le funzionalità disponibili e avviare un lavoro di indagine che deve essere dettagliato con approfondimenti specifici per ogni nodo di intersezione. L'approccio adottato indaga filtri di lettura per una categorizzazione dei software legata a) all'operatività dei sistemi (fig. 2), b) alla funzione del disegno (fig. 3), c) alla logica interpretativa del tratto grafico per la creazione delle immagini (fig. 4) e d) alla loro modalità di visualizzazione (fig. 5). (FMU).

\section{Possibili applicazioni in campo didattico e prossime sfide}

"Cosa succede quando tracciamo un segno su una superficie? Quali e quanti meccanismi cognitivi, emotivi, logici, simbolici, proiettivi vengono coinvolti e quali funzioni essi svolgono durante l'esecuzione di un disegno? Imparare a disegnare, acquisire il saper-fare un segno, implica parallelamente l'acquisizione di un'altra capacità, quella di saper-vedere ciò che di una data cosa si intende disegnare. II disegno non è solo riducibile a un repertorio di tecniche, ma è essenzialmente una forma di conoscenza: fa vedere il mondo, le cose e le loro reciproche relazioni in modo assolutamente unico; fa vedere ciò che altrimenti resterebbe invisibile" [Di Napoli 2004]. Esiste, "una differenza immensa tra il vedere una cosa senza la matita in mano, e il vederla disegnandola" [Valéry 1938, p. 27].

II mezzo informatico è diventato strumento di lavoro, matita aggiornata, che favorisce la regia complessiva del percorso progettuale, dal rilievo all'ideazione, dalla costruzione alla gestione. Gli 'immigrati digitali' hanno assistito a questa trasformazione della matita e in generale degli strumenti per la rappresentazione, non necessariamente applicandola alla sola professione, mentre i 'nativi digitali' sono cresciuti in ambienti virtuali accessibili e sono, quindi, più predisposti a utilizzare tecnologie di tipo informatico in sempre maggiori contesti [Prensky 200 I]. Una serie di domande e sfide devono ancora essere affrontate. In questo contributo ci siamo limitati ad aprire alcuni fronti di esplorazione, anche attraverso domande aperte, che guardano al campo didattico come terreno di sperimentazione operativa che può trasferire strumenti di lettura per la conoscenza attraverso un 'nuovo disegno tradizionale', anche nel rapporto con le altre discipline affini. Come possiamo valutare empiricamente e teoricamente i processi e le rappresentazioni rilevanti coinvolti nella com- 
prensione della rappresentazione visuo-spaziale? Dai quadri sinottici sopra proposti emerge come i software siano sempre più complessi e completi, anche se sviluppati per rispondere a funzioni specifiche. II panorama di prodotti tende a coprire una gamma sempre più ampia di funzionalità che si spingono ben oltre alla semplice possibilità di registrare un tratto grafico in forma digitale. Definizione, modifica dinamica, esportazione, condivisione, immersività, stampa prototipale, tour virtuali: l'esperienza diventa sempre più stimolante e foriera di intuizioni, coprendo svariati segmenti del processo ideativo e realizzativo. Creare contenuti

\begin{tabular}{|l|}
\hline Paint 3D \\
\hline Autodraw* \\
\hline Doodle3D \\
\hline Live Sketch \\
\hline Sketchbook \\
\hline Catchbook \\
\hline uMake \\
\hline Shapr3d \\
\hline Drag'n'Fly 3D \\
\hline Mental canvas \\
\hline 123d Design \\
\hline LoveSketch \\
\hline True2Form \\
\hline SkechUp \\
\hline Autocad \\
\hline Gravity Sketch \\
\hline VR Ink Pilot edition \\
\hline Geogebra* \\
\hline Deskriptiva \\
\hline
\end{tabular}

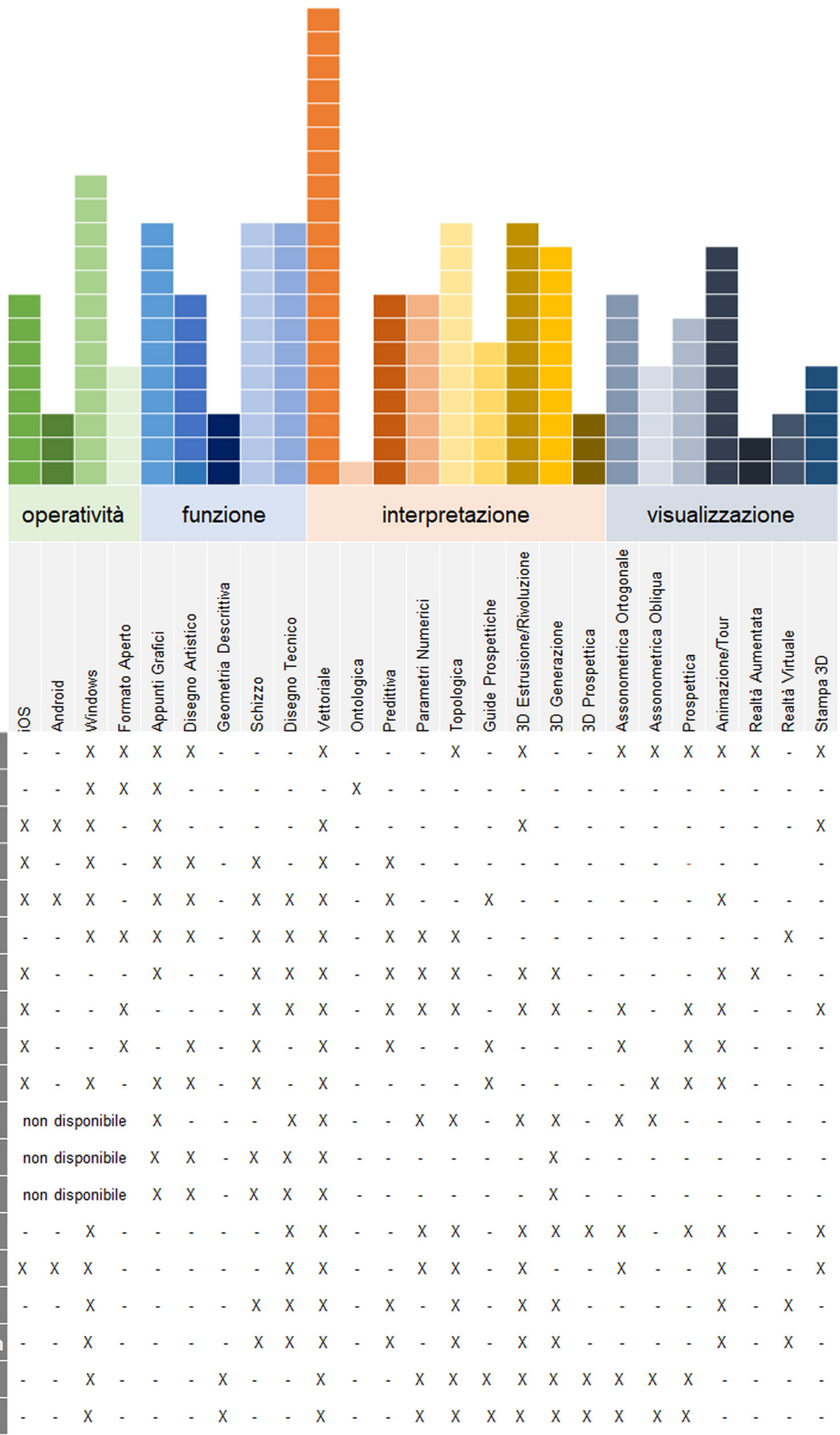


a più dimensioni sin dalle fasi di concezione grafica e spaziale sta diventando una necessità sempre più ricorrente, anche in ottica di una gestione sempre più collaborativa dei progetti. In riferimento a questo scenario, la didattica si sta interrogando sulle modalità di inserimento di tecniche innovative a supporto della formazione ed esamina in modi molto diversificati la possibilità di utilizzare strumenti hardware e software che consentano una compresenza e uno scambio sinergico tra il disegno analogico e quello digitale. Lo schizzo grafico, come forma di comprensione, interpretazione e progettazione, unisce il vedere con il pensare, il pensare con il fare. Mentre nel disegno manuale su carta è necessario formalizzare il tratto con regole codificate, l'interpretazione spaziale si sta trasferendo all'interno dei dispositivi di registrazione digitale tramite algoritmi informatici. L'interoperabilità tra sistemi digitali preserva l'integrità delle informazioni e le rende disponibili per successive elaborazioni. Si intravedono modalità completamente nuove di espressione, comprensione e comunicazione, dall'apprendimento, alla comunicazione, alla diffusione della conoscenza, in grado di rendere più semplice l'acquisizione di concetti analitici e geometrici e dunque aumentare le motivazioni per assumere una rinnovata consapevolezza. (M.M.B., F.M.U.).

Fig. 7. Comparazione schizzi urbani a mano libera e schizzi digitali che consentono percorsi perlustrazione nelle tre dimensioni guidati o liberi. Piazza Castello a Torino di Mario Manganaro, https:// www.mariomanganaro.it; Essex Street Market a New York di Chris Sharple, https://www.mentalcanvas. com/viewer/?path=gallery/ essexstreetmarket.
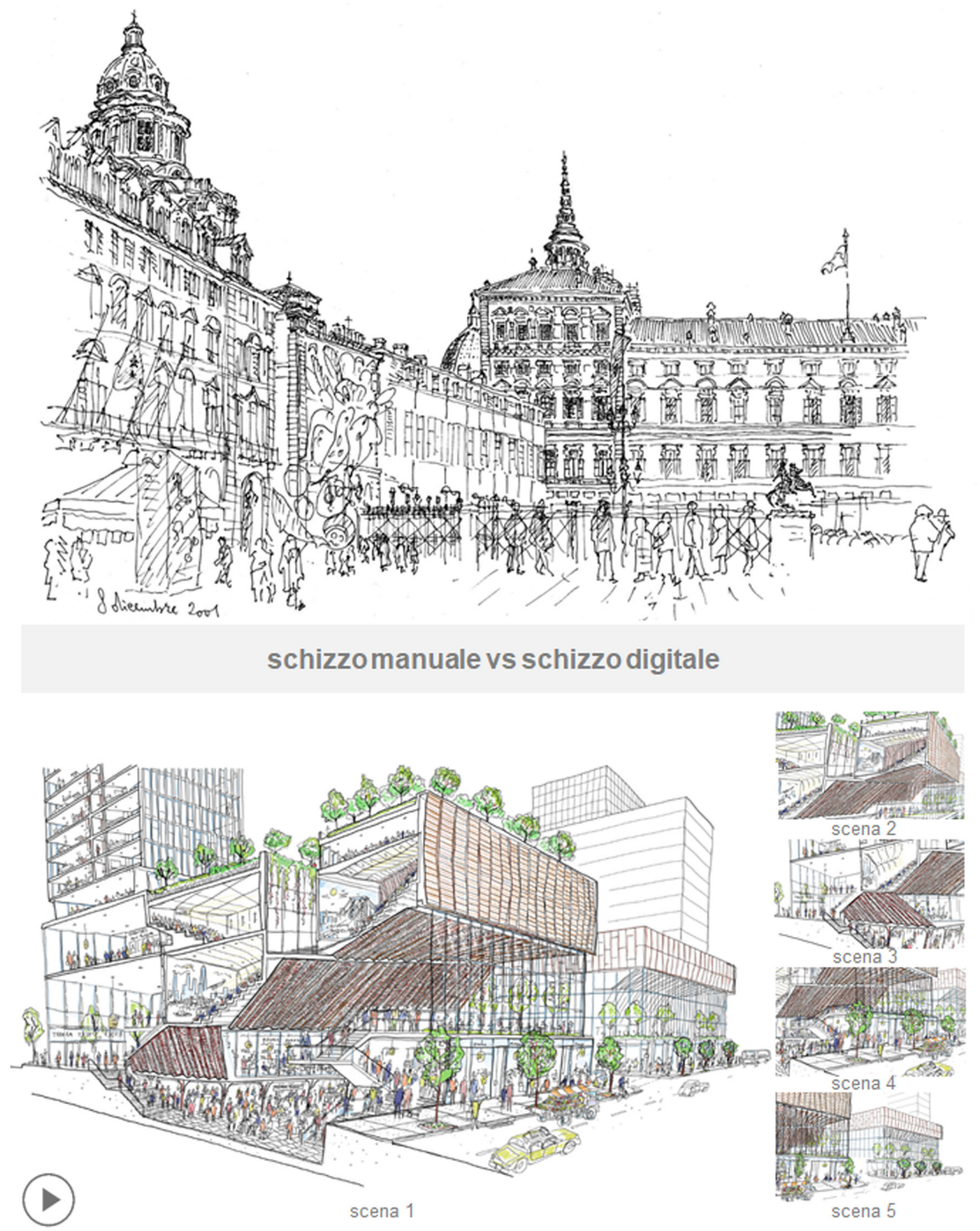


\section{Riferimenti bibliografici}

Altadonna Alessio, Arena Adriana, Manganaro Francesco (a cura di). (2018). Mario Manganaro “...un disegnatore generoso". Messina: EDAS Editori.

Bocconcino Maurizio Marco et al. (20 I0). Il disegno e l'ingegnere. Il disegno del territorio, della città e dell'architettura: applicazioni per allievi ingegneri e architetti. Torino: Levrotto \& Bella.

Di Napoli Giuseppe (2004). Disegnare e conoscere. La mano, l'occhio e il segno. Torino: Einaudi.

Galofaro Luca (1999). Eisenman digitale, uno studio dell'era dell'elettronica. Torino:Testo\&immagine.

Le Corbusier (1987). In Casabella, nn. 531-532 gennaio-febbraio 1987, p. 91.

Prensky Marc (200I). Digital Natives, Digital Immigrants. In On the horizon, vol. 9, n. 5, pp. I-6.

Ugliotti Francesca Maria et al. (2019). Evoluzione digitale della rappresentazione applicata all'Ospedale Galliera di Genova. In Belardi Paolo (a cura di). Riflessioni. L'arte del disegno/il disegno dell'arte. Atti del $41^{\circ}$ Convegno dei Docenti delle Discipline della Rappesentazione UID. Perugia, 19-2I settembre 2019, pp. 1775- 1780. Roma: Gangemi Editore.

Valéry Paul (1938). Degas danza disegno. Parigi: Gallimard.

\section{Sitografia}

https://getrocketbook.co.uk/products/rocketbook-wave

https://gfxspeak.com/wp-content/uploads/20 I5/05/from-CatchBook-video-Siemens-PLM-Labs-e I 4328397846 I 7.jpg

http://scenaridigitali.blogspot.com/2008/03/scenari-digitali.html

https://techprincess.it/moleskine-smart-writing-set-recensione

https://www.archdaily.com/902730/morpholio-trace-and-shapr3d-create-dragnfly-to-streamline-sketching-and-modelling https://www.autodraw.com/

https://www.geogebra.org/m/RWZ7dvsC\#material/KVKsY8sK

https://www.gravitysketch.com/

https://www.mariomanganaro.it

https://www.mentalcanvas.com

https://www.livescribe.com/

https://www.logitech.com/en-roeu/promo/vr-ink.html

https://www.webnews.it/20 I 7/04/I 2/autodraw-google-disegna-machine-learning/

https://www.youtube.com/watch? $=J A d R A v Z X d J U$

https://www.youtube.com/watch?v=jUCzfKUamts

https://www.youtube.com/watch?v=R6NIIY7UIMQ

https://youtu.be/FJfDSb--Up8

https://youtu.be/kMi_OHXXaTE

https://youtu.be/uarCOQ-3HkO

https://youtu.be/ZI_Gimw62mM

\section{Autori}

Maurizio Marco Bocconcino, Politecnico di Torino, maurizio.bocconcino@polito.it Francesca Maria Ugliotti, Politecnico di Torino, francesca.ugliotti@polito.it

Per citare questo capitolo: Bocconcino Maurizio Marco, Ugliotti Francesca Maria (2020). Interattività e interoperabilità nel disegno a mano libera: alcuni approcci digitali a supporto della didattica/Interactivity and interoperability in the freehand drawing: digital approaches supporting education. In Arena A., Arena M., Brandolino R.G., Colistra D., Ginex G., Mediati D., Nucifora S., Raffa P. (a cura di). Connettere. Un disegno per annodare e tessere. Atti del $42^{\circ}$ Convegno Internazionale dei Docenti delle Discipline della Rappresentazione/Connecting. Drawing for weaving relationships. Proceedings of the 42 th International Conference of Representation Disciplines Teachers. Milano: FrancoAngeli, pp. $119-138$ 


\title{
Interactivity and Interoperability in the Freehand Drawing: Digital Approaches Supporting Education
}

\author{
Maurizio Marco Bocconcino \\ Francesca Maria Ugliotti
}

\section{Abstract}

In the context of the digital revolution, the concept of 'connection' takes on a crucial value, enabling a transversal vision of knowledge, techniques and tools. The exchange of data in it environments is regulated by the ability to interact and function, measured by the degree of interoperability, which aims to ensure the best cooperation between systems or products. The article aims to investigate the relationship between analogue design and its digital reformulation - assisted, redefined, restructured, conformed, parameterized, even virtualized - exploring new possibilities of conceiving and constructing representation, either as a graphic schematization of a thought, in artistic or technical form, or as a tool to understand or prefigure. Specific hardware and software tools aim to establish a continuum between the freehand stroke and its analytical formulation within computer management. In this sense, terms such as interactivity and interoperability are provocatively introduced, which are not immediately associated with freehand drawing. Teaching is facing these approaches with ever-increasing expectations, evaluating the opportunities and methods for the inclusion of targeted training experiences. In this way, methods and techniques of representation useful for an enrichment of the outline of the future architect or engineer can be achieved already in the early academic years.
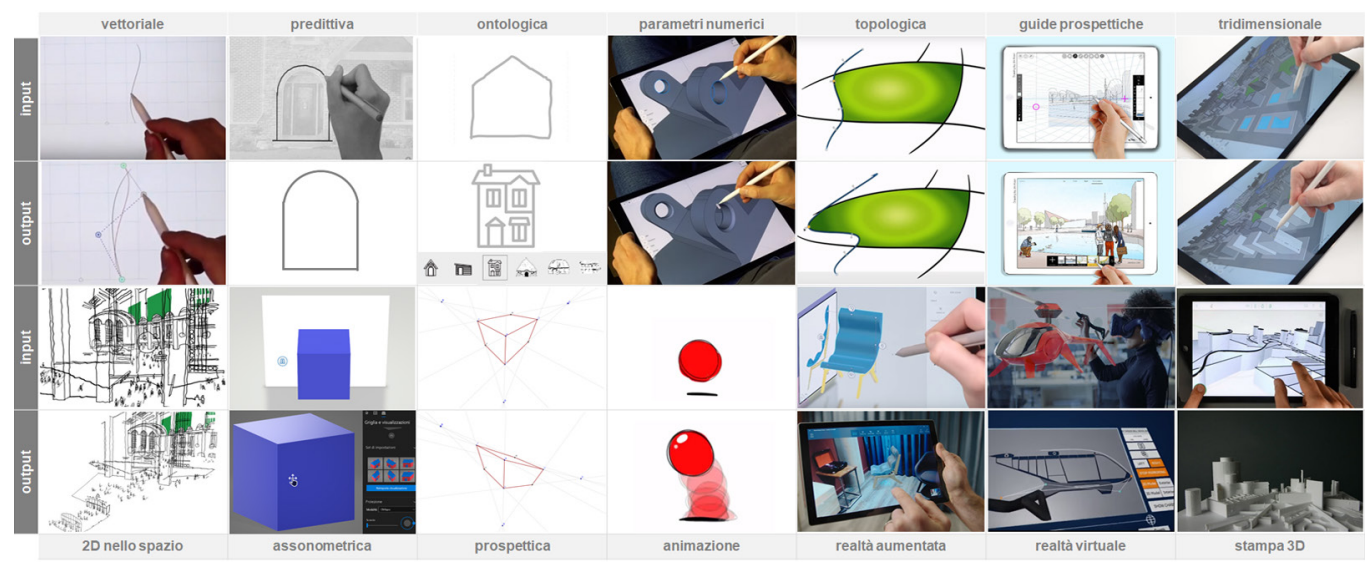


\section{Introduction}

In an increasingly competitive world, as regards the effectiveness and efficiency required of knowledge and project processes, digital capabilities in the management of representation systems become an essential and decisive factor. Drawing, as a graphic, informative and multimedia language, finds different expressions concerning the tools used. The common goal is to try to conceive an informative model, an 'intelligent' twin of the real or imagined object. This must be prepared and elaborated to govern its formal structure and therefore guarantee the transferability of the information associated with it and produced by it. The paper provides a reasoned, non-exhaustive summary of the hardware and software graphics tools supporting the drawing. We believe that its originality can be identified in promoting a ground of comparison and extended discussion of the support applications panorama (What new tools are there? Are they necessary or not? Do they add or subtract? What do they add and what do they take away?) in critical terms
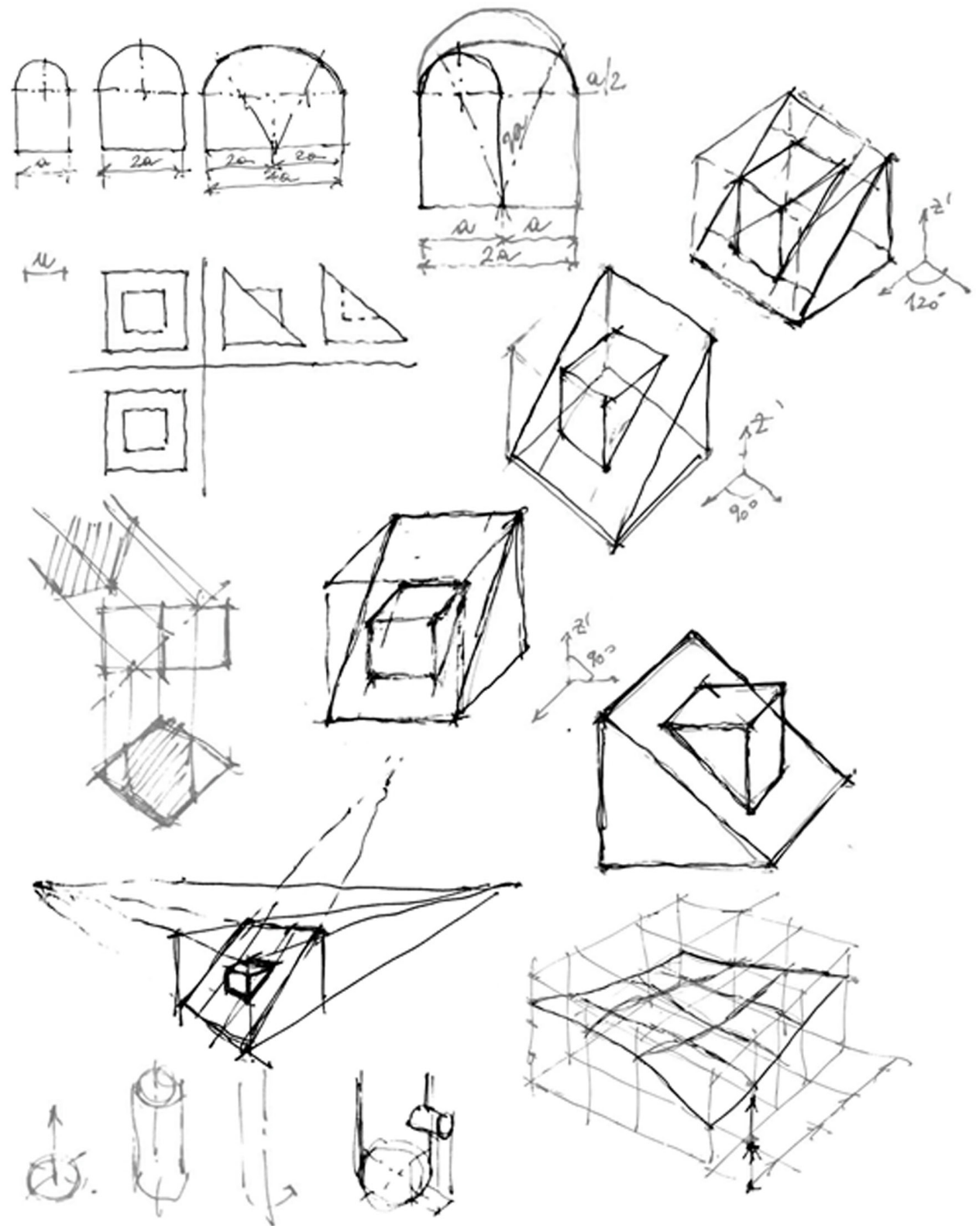
and with the purpose of description in progress. The figures accompanying the text and presenting this first analytical work, together with the references, are intended to provide comparative synoptic overviews in this field useful for more exhaustive in-depth analysis and subsequent integrations. This first phase of research starts to define a state of the art helpful to assess the evolution of the tools and the possibilities offered by them in a necessarily constantly updated and therefore changing context. For this reason, the critical review includes graphic tools not specifically dedicated to freehand drawing, that is analytical tools of interactive graphic analysis that assist the geometric construction of fundamental geometrical entities in the space and their relative descriptive nomenclature. (MMB).

\section{Some methodological considerations}

"The use of digital drawing becomes a useful means to make the exercise for the representation of spatial contents and their correct restitution in the usual projective models faster and didactically effective, if conducted with rigorous logic, without omitting the "freehand" drawing, but exploiting the specific characteristics of both" [Altadonna, Arena, Manganaro 20 I8, p. I8]. In this way, Mario Manganaro expressed himself on the teaching of drawing Faced with freehand drawing, which studies and highlights forms, ratios, compositional proportions that it is often not possible to collect 'at a glance', someone may have asked for something more than it already gives back. Enter the scene, change the point of view from time to time, apply other projective rules, even more sophisticated than perspective rules, such as those applied to planes parallel or orthogonal to the main ones in the picture. Tools that assist the freehand drawing with different degrees of response are appearing in the panorama of computer applications with increasing numbers. Some of them go as far as the spatial interpretation of what is drawn on the paper or screen plane. The two-way relationship that is established between figure in space and image on the projection plane is our raw material. It is elaborated within these software. The inverse perspective method or the backward restitution of the three-dimensional geometric configuration from axonometric projections are the most frequent areas of application in the following examples. The spatial problem of the determination of a solid given its orthogonal projection views appears instead, as expected, not solved.The level of conceptual abstraction is so high that it can only be determined, for now, by that powerful machine of vision that lies in the heads of the most trained subjects. While this is not possible for a computer, or rather, in the applications analyzed, it has not yet been led to try the exercise in a synthetic way. Only the power of calculation is put in place, which can prefigure billions of solutions progressively more in line with the one desired, probably without making the iteration converge towards the most suitable model [Bocconcino et al. 20I0]. Plane and solid geometry, as well as descriptive and projective representation, find new contexts of expression. The spatial genesis of the elements in the different processing environments is built in an interactive way between the observer who draws and the processing space within which he moves (fig. I). Le Corbusier writes that through the pencil "things remain within us for life", adding then "the camera is a tool of laziness because it entrusts a mechanism with the mission of looking for us. To draw personally, to follow profiles, to occupy surfaces, to recognize volumes, etc., is first of all to look, to be able to observe, perhaps to discover. At that moment the phenomenon of invention may occur. It is invented and also created; the whole being is dragged into action, this action is the capital point. The 'others' have remained passive, you have seen!' [Le Corbusier 1987, p. 9 I ]. In the following considerations it is not intended to provide new tools to laziness. Every tool looks appropriate to try to solve the knots of the conceptual vision of space in the minds of the young students. The delicate mechanism of spatial vision and conception is refined by following personal paths for everyone: the more you can provide the student with, the more he or she will perhaps be able to recognize his or her own. (M.M.B, F.M.U). 


\section{First critical review of digital support tools for freehand drawing}

In the engineering and architectural sector, the adoption of informatics tools is aimed at solving complex problems more efficiently. Graphic applications play an important role in this context as they allow an object to be reproduced and displayed in the space from a two-dimensional representation. Eisenman argues that the computer gives you the ability to do things you could not do directly, from mental conception to execution by hand, and promotes a process of continuous refinement of conceptualized models [Galofaro 1999]. Digital evolution has introduced epoch-making changes in image production and technical drawing. The first one in the 1970s when there was a transition from the technographer to Computer Aided Design (CAD) systems. The second in the 2000s with the advent of the parametric digital Building Information Modelling (BIM) methodology. Thanks to

iOs

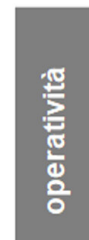

In quanto sistema chiuso, riesce a garantire massima compatibilità con i prodotti Apple e dispone del maggio numero di applicazioni dedicate. android

Sistema open source per eccellenza, risponde con grande versatilità e compatibilità ai dispositivi sul
Operante anche su dispositivi tablet, garantisce prestazioni più vicine ad un computer e consente quindi una qualità progettuale elevata

Information and Communication Technologies (ICT), designers' creativity is supported by increasingly advanced generation and control systems. Focusing on the digital transformation of analog input, the main hardware components have developed from the invention of digitizers that led to the creation of touch screens. These, patented in 1969, were initially diffused in the information and automatic teller machines for the public. The digitizer technology makes it possible to receive analog information - objects, images or signals - and store it in real time in a digital format that can be managed by computer using the principle of electromagnetic induction. Since the 2000s, graphic tablets and tablets have been readily

\begin{tabular}{|c|c|c|c|c|}
\hline & appunti grafici & $\begin{array}{l}\text { geometria } \\
\text { descrittiva }\end{array}$ & $\begin{array}{c}\text { schizzoarchitettonico } \\
\text { urbano/territoriale }\end{array}$ & disegnotecnico \\
\hline & $\begin{array}{l}\text { Sopra fogli o taccuini, } \\
\text { per annotare e formulare } \\
\text { relazioni geometriche } \\
\text { tratte da fonti transitorie } \\
\text { o immagini con il fine di } \\
\text { ricordare, leggere, } \\
\text { schematizzare, } \\
\text { semplificare. }\end{array}$ & $\begin{array}{l}\text { Rappresenta in modo } \\
\text { univoco, non ambiguo, } \\
\text { attraverso determinate } \\
\text { costruzioni geometriche, } \\
\text { mediante uno o più piani } \\
\text { di proiezione, figure nello } \\
\text { spazio tramite enti } \\
\text { geometrici fondamentali. }\end{array}$ & $\begin{array}{l}\text { Disegno schematico di edifici } \\
\text { o parti di edifici (eidotipo se } \\
\text { preparatorio a successivi } \\
\text { approfondimenti conoscitivi) } \\
\text { e del loro contesto urbano o } \\
\text { territoriale. Contiene } \\
\text { informazioni di carattere } \\
\text { quantitativo (in termini di } \\
\text { assialità, modularità e } \\
\text { proporzioni) e qualitativo } \\
\text { (contesto, funzioni, materiali, } \\
\text { ecc.). }\end{array}$ & $\begin{array}{l}\mathrm{Si} \text { occupa di fornire, } \\
\text { attraverso i metodi di } \\
\text { rappresentazione, dati di } \\
\text { misura e di forma utili per la } \\
\text { sezione di manufatti fisici di } \\
\text { vario genere. E una } \\
\text { rappresentazione di elementi } \\
\text { geometrici nello spazio, le } \\
\text { cui regole base sono dettate } \\
\text { dalla geometria descrittiva, } \\
\text { ai quali sono applicati codici } \\
\text { e standard grafici specifici } \\
\text { (norme tecniche). }\end{array}$ \\
\hline
\end{tabular}

adopted in specific areas of drawing strongly characterized by creative, artistic and graphic functions, taking advantage of the possibility of connecting special devices to simulate freehand drawing, such as nibs or airbrushes. In detail, what is traced on the tablet surface with a pen is displayed on the computer monitor; while it is recorded directly on a resistive or capacitive screen in the case of the tablet. There are many aspects that characterize these devices: from usability to ease of use, from resolution to pressure sensitivity to the 


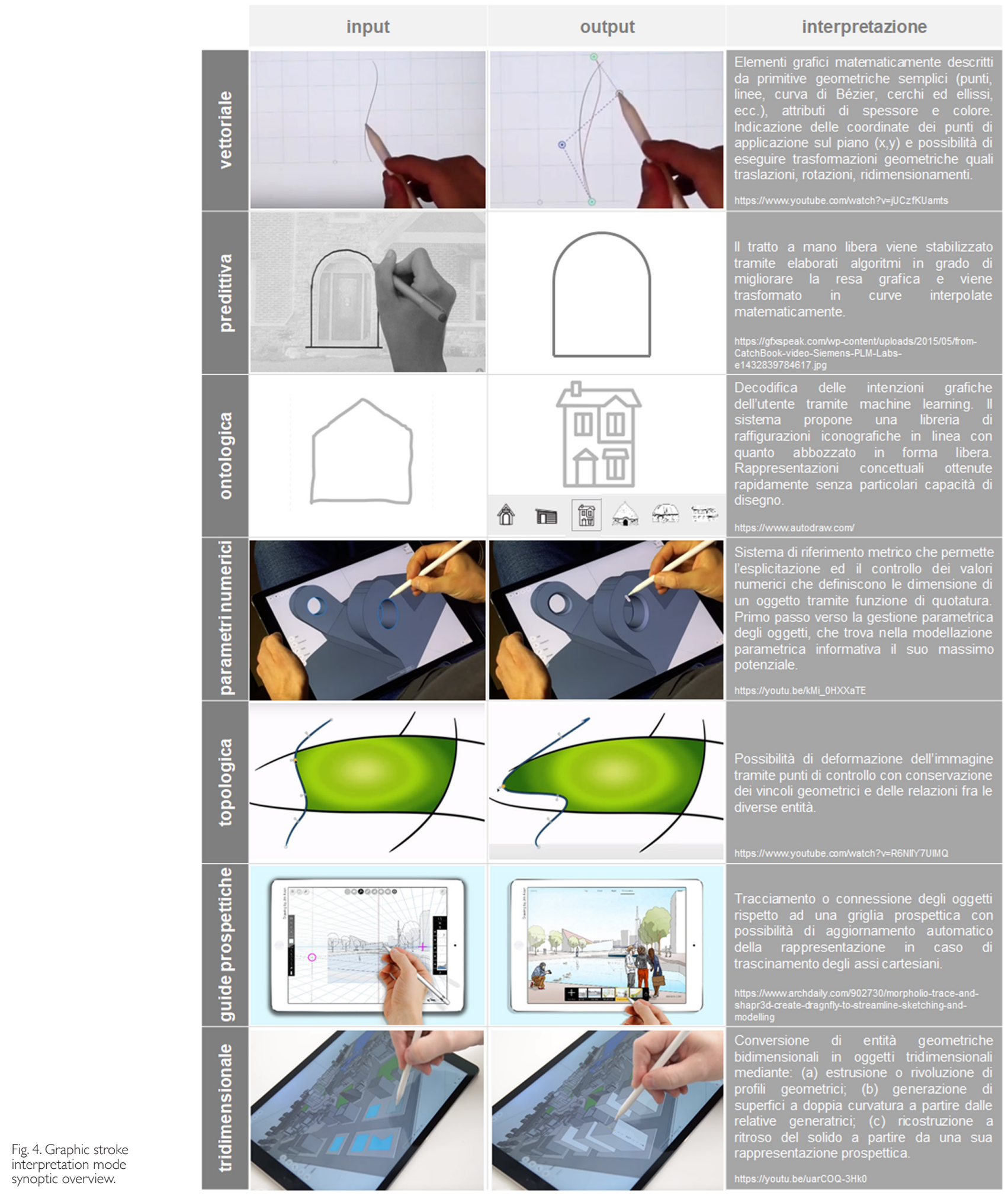




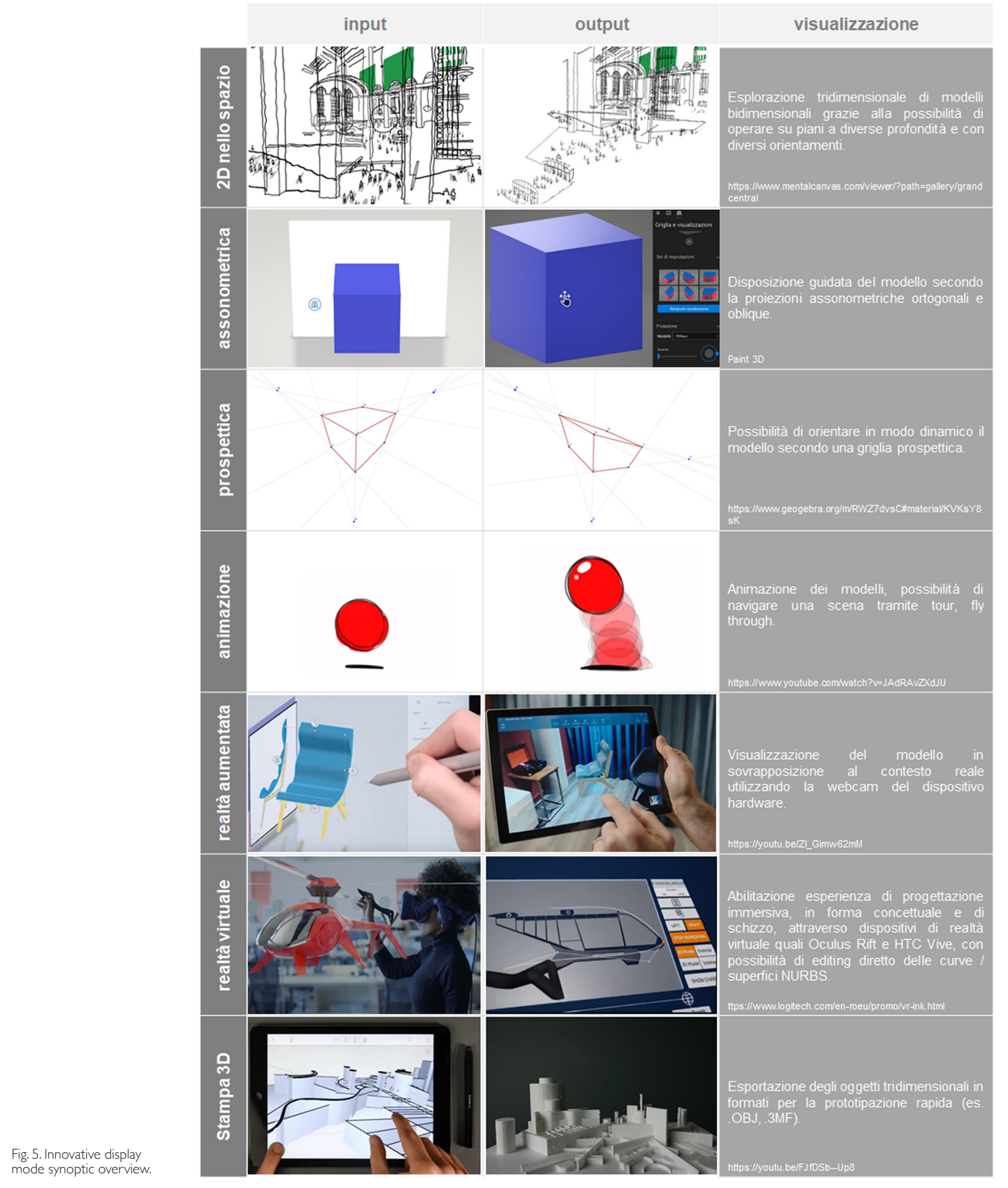


screen and the type of nib. The tools available to professionals are enriched but at the same time the number of users who can obtain digital results without abandoning writing and drawing on paper is growing by Smart Writing systems. Through a special pen and a smart notebook it is possible to instantly transfer notes, drafts, diagrams, sketches, in the cloud, transforming them into vector data (rocketbook.co.uk, 2020; moleskine-smart-writing-set, 2020, livescribe SmartPen, 2020). Other technological possibilities make it possible to design and create solid figures in space using 3D pens, which deposit plastic filaments through the nozzle of an extruder to materialize those conceived virtually through rapid prototyping and $3 \mathrm{D}$ printing. The good interaction with hardware devices is achieved through the use of dedicated software that allows the conversion of finger pressure or peripheral adopted in graphical strokes. Some of these tools initially evolved in industrial and automotive production environments to meet specific needs for managing parametric curves in space and prototyping. The eye, hand and mind interdependence is extremely useful for learning. In this sense, drawing software has been oriented in recent years to manage the coexistence of the traditional form with the digital one. From a preliminary survey of the literature and the market, several applications are available that can obtain a satisfactory perceptive quality by fulfilling the role of a cognitive instrument performed by the design. Despite their very wide diffusion, applications referring exclusively to artistic design have been excluded from the review, as they do not coincide with the objectives of the study, although this function has been considered. The table shown in fig. 6 is configured as a graphic resource to facilitate the comparison between the available functionalities and to start an investigation work that must be detailed with specific insights for each intersection node. The adopted approach investigates interpretation filters for the software categorization linked (a) to the systems operation (fig. 2), (b) to the drawing functions (fig. 3), (c) to the graphic stroke interpretation logic for the creation of the images (fig. 4) and (iv) to their display mode (fig. 5). (FMU).

\section{Possible educational applications and next challenges}

"What happens when we make a mark on a surface? What and how many cognitive, emotional, logical, symbolic, projective mechanisms are involved and what functions do they perform during the execution of a drawing? Learning to draw, acquiring the ability to make a sign, implies at the same time the acquisition of another ability, that of being able to see what we intend to draw of a given thing. Drawing is not only reducible to a repertory of techniques, but is essentially a form of knowledge: it makes us see the world, things and their reciprocal relations in an absolutely unique way; it makes us see what would otherwise remain invisible" [Di Napoli 2004].There is "an immense difference between seeing something without a pencil in your hand, and seeing it by drawing it" [Valéry 1938, p. 27].

Digital tools have become a working tool, an updated pencil, which supports the overall direction of the project, from survey to design, from construction to management. Digital immigrants have experienced this transformation of the pencil and in general of the tools for representation, not necessarily applying them to their profession. While digital natives have grown up in accessible virtual environments and are, therefore, more inclined to use information technology in more and more contexts [Prensky 200 I]. A series of questions and challenges still need to be addressed. In this contribution we have limited ourselves to opening some lines of exploration, also through open questions, which look at didactics as a field of operational experimentation that can transfer learning tools for knowledge through a new traditional drawing, also in the relationship with other related disciplines. How can we empirically and theoretically assess the relevant processes and representations involved in understanding visual-spatial representation? From the synoptic overviews presented above, it emerges how software is increasingly complex and complete, even if developed to respond to specific functions. The product offering covers an increasingly wide range of functions that go far beyond the simple possibility of recording a graphic stroke in digital form. Definition, dynamic modification, export, sharing, immersivity, prototype printing, virtual tours: the experience becomes more and more stimulating and a source of inspiration, 
covering various aspects of the design and implementation process. Creating multi-dimensional content from the graphic and spatial design phases is becoming an everyday necessity, also with a view to increasingly collaborative project management. With reference to this scenario, the teaching is questioning how to introduce innovative techniques to support training and examines in very different ways the possibility of using hardware and software tools that allow a coexistence and a synergic exchange between analogical and digital design. The graphic sketch, as a form of understanding, interpretation and design, combines

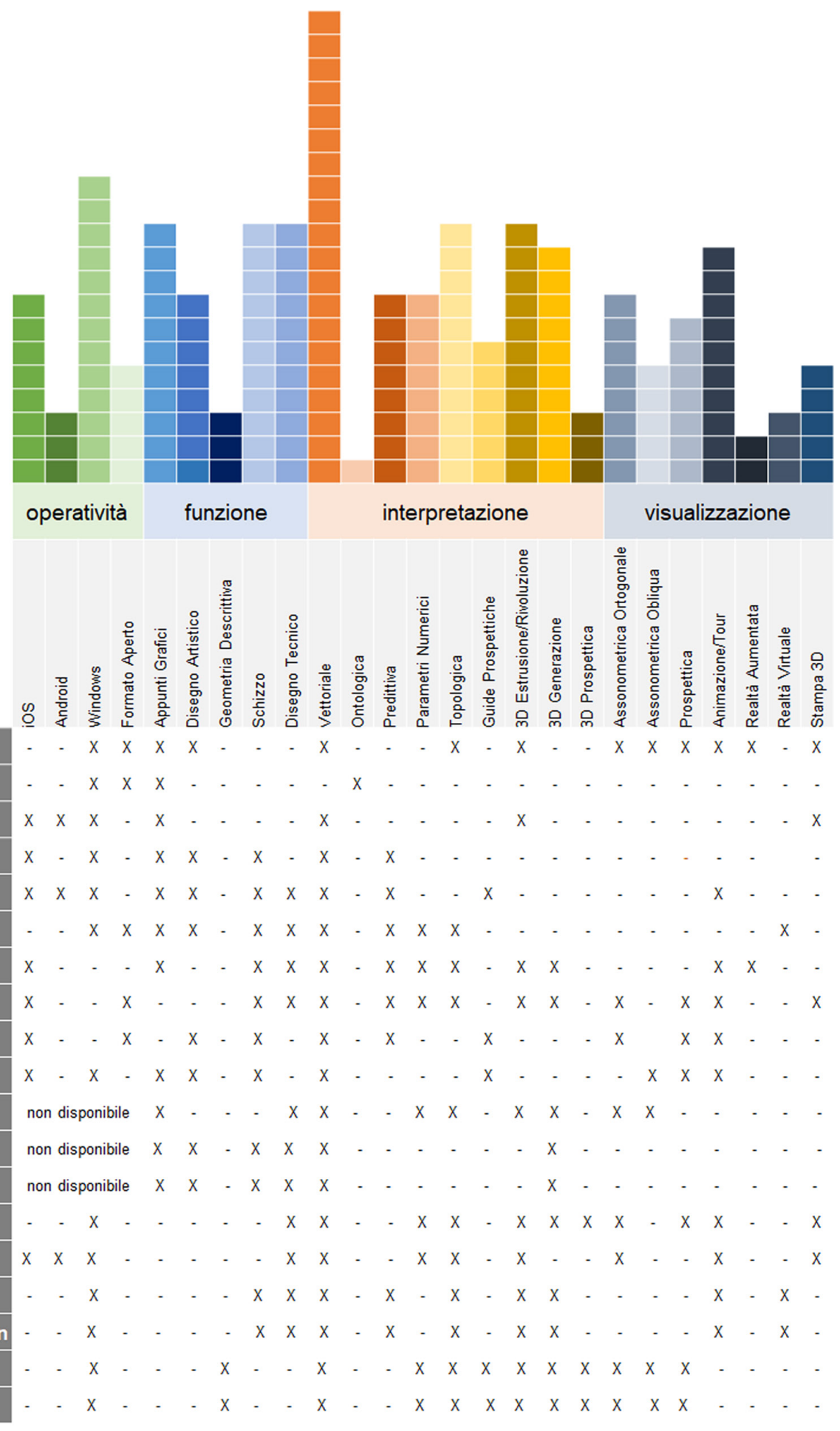


seeing with thinking, thinking with doing. While in paper manual drawing it is necessary to formalize the stroke with codified rules, spatial interpretation is being transferred within digital recording devices through computer algorithms. Interoperability between digital systems preserves the integrity of the information and makes it available for further processing. Completely new ways of expression, understanding and communication, from learning to communicate to the dissemination of knowledge, can be envisaged, making it easier to acquire analytical and geometrical concepts and thus increasing the motivation to assume a renewed awareness. (M.M.B., F.M.U.).

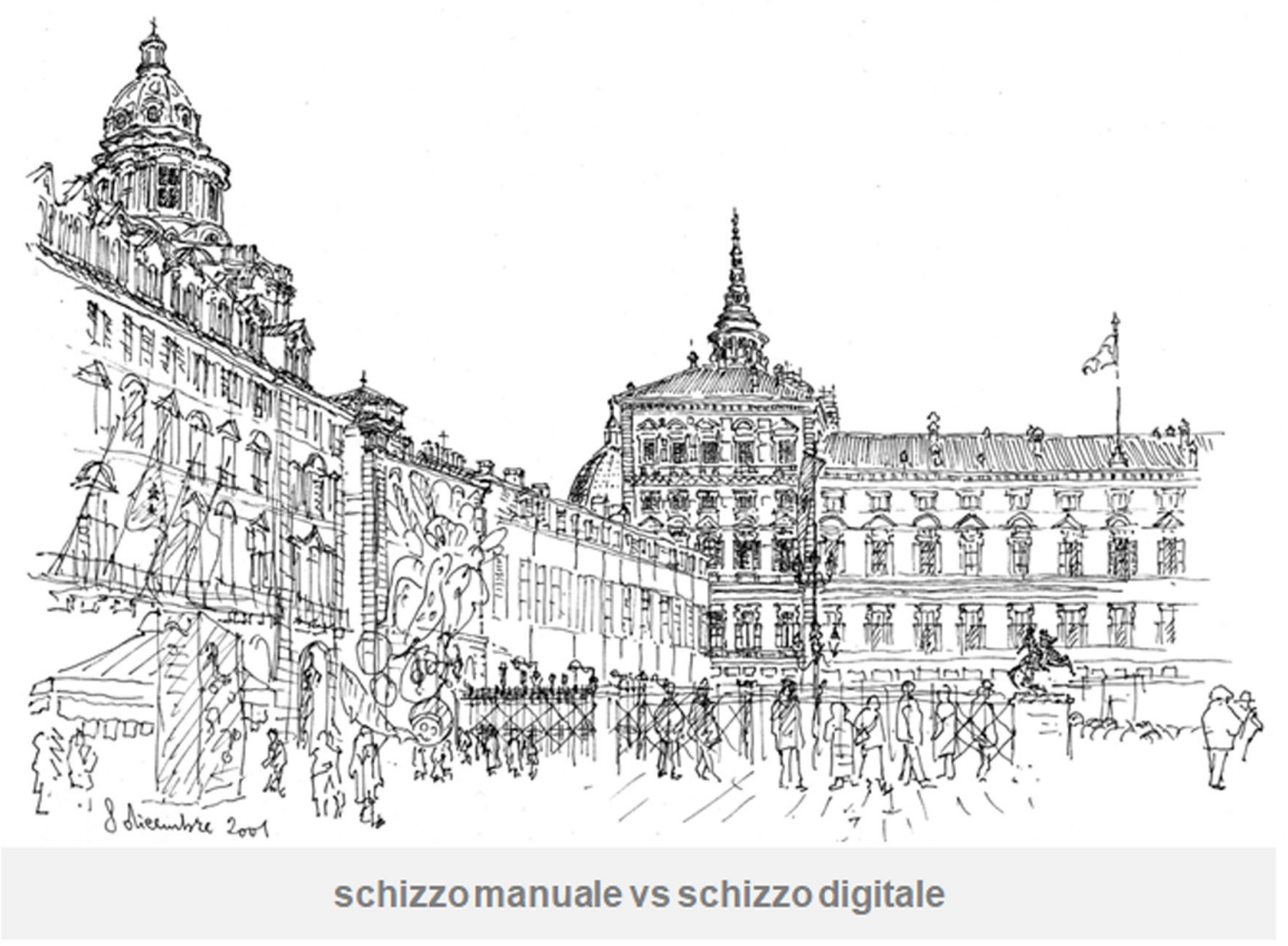

Fig. 7. Freehand and digital urban sketches comparison enabling
guided or free exploration pathways in the three dimensions.

Piazza Castello in Turin by Mario Manganaro, https:// www.mariomanganaro.it; Essex Street Market in New York by Chris Sharple, https://www. mentalcanvas. com/ viewer/?path= gallery/ essexstreetmarket.
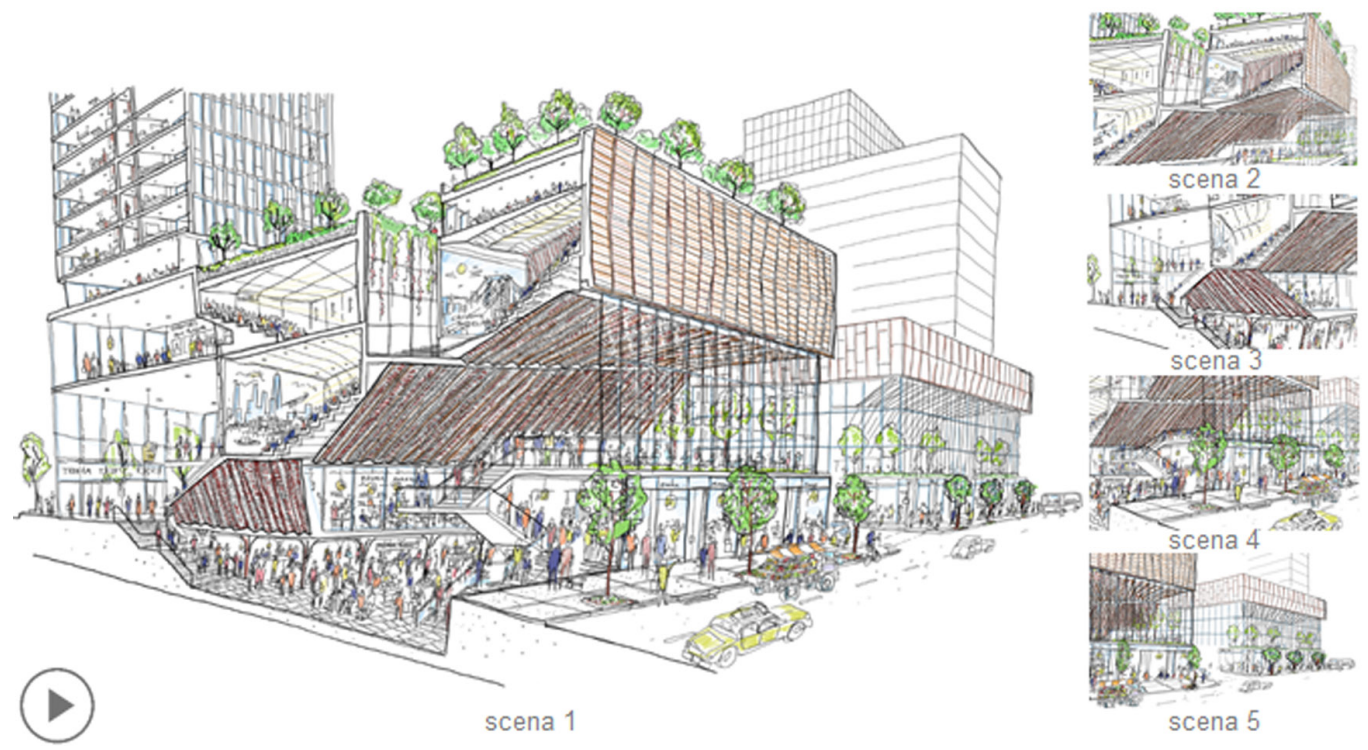
scena 3
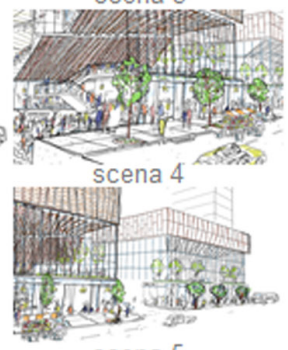

scena 5 


\section{References}

Altadonna Alessio, Arena Adriana, Manganaro Francesco (a cura di) (20l8). Mario Manganaro “...un disegnatore generoso". Messina: EDAS Editori.

Bocconcino Maurizio Marco et al. (20 I0). Il disegno e l'ingegnere. Il disegno del territorio, della città e dell'architettura: applicazioni per allievi ingegneri e architetti. Torino: Levrotto \& Bella.

Di Napoli Giuseppe (2004). Disegnare e conoscere. La mano, l'occhio e il segno. Torino: Einaudi.

Galofaro Luca (1999). Eisenman digitale, uno studio dell'era dell'elettronica. Torino:Testo\&immagine.

Le Corbusier (1987). In Casabella, nn. 531-532 gennaio-febbraio 1987, p. 91.

Prensky Marc (200I). Digital Natives, Digital Immigrants. In On the horizon, vol. 9, n. 5, pp. I-6.

Ugliotti Francesca Maria et al. (2019). Evoluzione digitale della rappresentazione applicata all'Ospedale Galliera di Genova. In Belardi Paolo (a cura di). Riflessioni. L'arte del disegno/il disegno dell'arte. Atti del $41^{\circ}$ Convegno dei Docenti delle Discipline della Rappesentazione UID. Perugia, 19-2I settembre 2019, pp. 1775- 1780. Roma: Gangemi Editore.

Valéry Paul (1938). Degas danza disegno. Parigi: Gallimard.

\section{Website}

https://getrocketbook.co.uk/products/rocketbook-wave

https://gfxspeak.com/wp-content/uploads/20 I5/05/from-CatchBook-video-Siemens-PLM-Labs-e I 4328397846 I 7.jpg

http://scenaridigitali.blogspot.com/2008/03/scenari-digitali.html

https://techprincess.it/moleskine-smart-writing-set-recensione

https://www.archdaily.com/902730/morpholio-trace-and-shapr3d-create-dragnfly-to-streamline-sketching-and-modelling https://www.autodraw.com/

https://www.geogebra.org/m/RWZ7dvsC\#material/KVKsY8sK

https://www.gravitysketch.com/

https://www.mariomanganaro.it

https://www.mentalcanvas.com

https://www.livescribe.com/

https://www.logitech.com/en-roeu/promo/vr-ink.html

https://www.webnews.it/20 I 7/04/ I 2/autodraw-google-disegna-machine-learning/

https://www.youtube.com/watch?v=JAdRAvZXdJU

https://www.youtube.com/watch?v=jUCzfKUamts

https://www.youtube.com/watch?v=R6NIIY7UIMQ

https://youtu.be/FJfDSb--Up8

https://youtu.be/kMi_OHXXaTE

https://youtu.be/uarCOQ-3HkO

https://youtu.be/ZI_Gimw62mM

\section{Authors}

Maurizio Marco Bocconcino, Politecnico di Torino, maurizio.bocconcino@polito.it

Francesca Maria Ugliotti, Politecnico di Torino, francesca.ugliotti@polito.it

To cite this chapter: Bocconcino Maurizio Marco, Ugliotti Francesca Maria (2020). Interattività e interoperabilità nel disegno a mano libera: alcuni approcci digitali a supporto della didattica/Interactivity and interoperability in the freehand drawing: digital approaches supporting education. In Arena A., Arena M., Brandolino R. G., Colistra D., Ginex G., Mediati D., Nucifora S., Raffa P. (a cura di). Connettere. Un disegno per annodare e tessere Atti del $42^{\circ}$ Convegno Internazionale dei Docenti delle Discipline della Rappresentazione/Connecting. Drawing for weaving relationships. Proceedings of the 42th International Conference of Representation Disciplines Teachers. Milano: FrancoAngeli, pp. I 19 - 138 